\title{
ЭМИГРАЦИЯ ЕВРЕЕВ ИЗ РОССИИ
}

\section{EMIGRATION OF JEWS FROM RUSSIA \\ Li Zhongbao}

Summary: This article aims to trace the movement of the Russian Jewish emigration in different historical periods of the Russian state. The author of the study pays special attention to the fact that the existing scientific research on this issue, both Russian and foreign, is characterized by fragmentation, since they affect only a certain stage or a certain area of Russian Jewish emigration. This article attempts to accumulate the scientific experience of publications on this problem, to consider the process of Russian Jewish emigration holistically, which will reveal the existence of the emigration history of Jews.

Keywords: Russia, Jews, emigration, emigration wave, emigration processes, anti-Semitism.

\author{
Ли Чжунбао \\ Ланьчжоуский университет, Ланьчжоу, Китай \\ lizhb19@lzu.edu.cn
}

Аннотация: Настоящая статья имеет своей целью проследить движение русской еврейской эмиграции в разные исторические периоды российского государства. Автором исследования обращается особое внимание на то, что существующие научные изыскания по данному вопросу, как российские, так и зарубежные, характеризуются фрагментарностью, поскольку затрагивают лишь определённый этап или определенную область русской еврейской эмиграции. В данной статье предпринята попытка аккумулировать научный опыт публикаций по указанной проблеме, рассмотреть процесс русской еврейской эмиграции целостно, что позволит обнаружить существование эмиграционной истории евреев.

Ключевые слова: Россия, евреи, эмиграция, эмиграционная волна, эмиграционные процессы, антисемитизм.

эмигрантов в Израиль до и после окончания "холодной войны"» [17], диссертация Ван Сяньсянь «Исследование по русской еврейской эмиграции в конце XX века» [23], диссертация Чжан Цзюань «Политика антисемитизма в царской России и его влияние на евреев» [14] и некоторые другие, которые являются концептуально важными для настоящего исследования $[13 ; 15 ; 16 ; 18 ; 19 ; 20 ; 21$; $22 ; 24 ; 25]$.

Причиной еврейской эмиграции в период царской России, в дополнение к ограничениям на место жительства и деятельности евреев в стране, оказывается и тот факт, что русские евреи лишились политических, экономических, культурных и других свобод, что и стало одной из причин появления волны антисемитизма в обществе. Первая волна антисемитизма со стороны российского правительства произошла после убийства Александра II 1 марта 1881 года, которое привело к нападению на еврейский народ и усилило преследование евреев: евреи, проживавшие в 166 населенных пунктах, были убиты, тысячи еврейских домов были разрушены, а имущество многих еврейских семей было конфисковано. Второе массовое преследование евреев произошло между 1903 и 1904 годами. В апреле 1903 года российское правительство жестоко убило 49000 евреев, живущих в Кишинёве, что вызвало коллективную неудовлетворенность правительством со стороны отечественной и зарубежной интеллигенции. С 29 августа по 1 сентября 1903 года Николай II распорядился уничтожить гомельских евреев, что вызвало первую антиправительственную борьбу русских евреев за самооборону. В январе 1904 года разразилась русско-японская война, в которую вступили почти 3000 евреев, многие из них были принесены в жертву на поле боя. 17 октября 1905 
года Николай II издал указ и начал антисемитские коллективные погромы. Согласно статистическим данным, во время гражданской войны между 1905 и 1907 годами было разрушено 660 населенных пунктов, произошло более 500 терактов и было убито более 20000 евреев, в частности в Киеве, Одессе, Кишинёве, Лодзи, Вильне, Минске. Кроме того, такие факторы, как пробуждение еврейского национального самосознания, сионизм, под влиянием которого еврейский народ надеется вернуться на свою родину, и тяга к либеральной демократии и процветающему экономическому ландшафту в Соединенные Штаты (далее США) также являются реальными причинами ухода евреев из России.

Согласно статистике, в период с 1881 по 1914 год более 2 миллионов русских евреев эмигрировали из России в разные страны мира [8]. В этой продолжающейся волне эмиграции 78,6\% евреев переселились в США, В общей сложности 1557100. Ниже приводятся подробные данные русских еврейских эмигрантов в США (Табл. 1).

Таблица 1.

Эмиграция евреев из России в 1881-1914 гг. [8]

\begin{tabular}{|c|c|c|} 
Страна иммиграции & $\begin{array}{c}\text { Численность } \\
\text { (в тыс. чел.) }\end{array}$ & $\begin{array}{c}\text { Доля от всех евреев- } \\
\text { эмигрантов из России } \\
\text { (в \%) }\end{array}$ \\
\hline США & 1557 & 76,8 \\
\hline Великобритания & 120 & 6,1 \\
\hline Аргентина & 75 & 3,8 \\
\hline Канада & 65 & 3,3 \\
\hline Эрец-Исраэль & 43 & 2,2 \\
\hline Франция & 40 & 2,0 \\
\hline Южная Африка & 36 & 1,8 \\
\hline Германия & 21 & 1,0 \\
\hline Египет & 12 & 0,6 \\
\hline Бельгия & 8 & 0,4 \\
\hline Другие & 3 & 0,1 \\
\hline
\end{tabular}

Кроме того, в период русской еврейской эмиграции доля мужского населения составляла 56\%, еврейские дети в возрасте до 14 лет составляли 24,4\% от общего числа эмигрантов, а люди в возрасте от 14 до 44 лет 69,8\%. Следовательно, в этой группе еврейских эмигрантов подавляющее большинство - молодые люди, что, несомненно, обеспечивало богатые трудовые ресурсы для стран, в которые они переехали.

Советское еврейское эмиграционное движение было тесно связано с политикой в отношении иудеев и их положением в СССР. Процесс движения советских еврейских эмигрантов может быть охарактеризован как непрерывный (не ограничивающийся 69-летним существованием
Советского государства) по нескольким причинам. С 1914 по 1918 год длилась Первая мировая война, в которой участвовали сотни тысяч русских евреев. В 1914 году число русских евреев, участвовавших в войне, составляло 400000. К 1916 году их число возросло до 500000 [3]. Несправедливо относились к ним и в военных лагерях. В частности, конфликтные ситуации разворачивались между евреями и казаками. В тот период вся российская армия также предприняла ряд антиеврейских мер, в результате которых тысячи невинных солдат-евреев были депортированы с фронта во внутренние районы России, многие евреи были подвержены обвинениям и отправлены в военные суды. После Февральской революции временное правительство попыталось снять все ограничения на евреев. И в то же время сионизм также развился в России: сионистский лагерь насчитывал порядка 300000 человек, которые создали большое количество еврейских политических организаций, таких как «Масорет ве-херут», «Сионистская социалистическая рабочая партия» и «Социалистическая еврейская рабочая партия» [3]. Важной практикой сионистского движения оказалось эмиграционное движение - возвращение на Святую Землю. Ученые, как правило, используют термин «алия» для обозначения инцидента с евреями в изгнании в различных уголках света. До Октябрьской революции, первая Алия в России произошла в 1882 и 1903 годах, а вторая - в 1904 и 1914 годах [10].

После Октябрьской революции в России воцарилась советская власть. 15 ноября 1917 г. советское правительство обнародовало «Декларацию прав народов России», в которой содержалась относительно либеральная политика в отношении евреев на основе равенства с другими этническими группами, что гарантировало политические, экономические и культурные права и интересы евреев. Примечательно, что на советской политической арене стало активно действовать большое число еврейских деятелей [3], из которых самым известным был лидер КПСС Л.Д. Троцкий.

С 1917 по 1923 год на территории бывшей Царской империи произошла третья волна еврейской эмиграции. После Октябрьской революции 1917 года Польша, Турция, Финляндия и другие страны получили независимость. После гражданской войны большое количество евреев начали переселяться в крупные города, что привело к чрезвычайно высокому уровню урбанизации русских евреев. В 1922 году количество советских евреев достигло более 300 миллионов, в том числе сотни тысяч беженцев и тех, кто вернулся в СССР после изгнания в период царской России. С 1918 по 1922 год в результате серии войн, голода и массовых погромов, уровень еврейской рождаемости резко снизился. В то время около 300 тысяч человек из более двух миллионов евреев [3] покинули СССР (в основном в Польшу и Румынию, а затем эти евреи эмигрировали в США, Палестину, Южную 
Африку, Канаду и другие страны). Октябрьская революция 1917 года и последовавшая за ней Гражданская война не только катализировали первую волну еврейской эмиграции в период СССР, но и придали этому движению немыслимый политический подтекст. Это породило термины «белая эмиграция» или «антибольшевистская эмиграция», которые использовались для обозначения этого эмиграционного движения. С 1924 по 1929 год произошла четвертая алия в СССР [10]. Из-за ограничений США, наложенных на еврейских эмигрантов, подавляющее большинство (почти 82 000) евреев были демобилизованы обратно в Палестину. Эта волна эмиграции, вызванная, главным образом, экономическим кризисом в Польше, привела к упадку еврейских ремёсел и торговли.

С 1929 по 1939 год до начала Второй мировой войны произошла пятая волна еврейской эмиграции. В общей сложности около 250000 евреев переехали в Палестину, которая в то время находилась под опекой Британии. Большинство из них были из стран Западной Европы, таких как Германия, Австрия и Польша.

В 1948 году был образован Израиль, что послужило причиной массовой волны еврейской эмиграции из СССР. В ранний период (1944-1967 гг.) 20000-25000 евреев с польским и чехословацким гражданством бежали нелегально, многие из которых служили на оккупированных во время Второй мировой войны территориях СССР. В конце 1948 года более 100000 евреев переехали в Израиль. К концу 1951 года это число возросло до 690000 человек.

После Сталина в 1953 году Советский Союз вступил в период «оттепели». За этот период в общей сложности 6916 советских евреев переехали в Израиль, и почти 25000 евреев избежали в Польшу [6].

В июне 1967 года между арабскими и израильскими странами разразилась «шестидневная война» (третья война на Ближнем Востоке). Война пробудила национальное самосознание советских евреев [4, с. 152] и привела к росту легальной эмиграции в Израиль в советском обществе. Советское правительство также начало разрешать евреям эмигрировать в новое государство и выдавать им визы с целью налаживания отношений между СССР и Израилем.

К 1979 году движение советских еврейских эмигрантов достигло своего пика. Однако под влиянием Афганской войны в конце 1979 года, волна этой эмиграции пошла на спад. В 1982 году только 2688 евреев получили выданные правительством выездные визы, в 1983 году их число сократилось до 1315, и к 1984 году только 896 получили разрешение на эмиграцию. После прихода к власти М. С. Горбачева, советская еврейская эмиграция получила новый поворот. С конца 1980-х до начала 1990х годов сотни тысяч евреев эмигрировали за границу. Резюмируя вышесказанное, приведём подробные данные о численности еврейских эмигрантов из СССР в другие с 1954 по 1991 год (Табл. 2):

Таблица 2.

Еврейская эмиграция из СССР в 1954-1991 гг. [9]

\begin{tabular}{|c|c|c|c|c|}
\hline Период & Всего & В Израиль & $\begin{array}{c}\text { В другие } \\
\text { страны }\end{array}$ & $\begin{array}{c}\text { \% эмигри- } \\
\text { ровавших в } \\
\text { Израиль }\end{array}$ \\
\hline $1954-58$ & 1090 & 1090 & 0 & 100 \\
\hline $1959-69$ & 9125 & 9125 & 0 & 100 \\
\hline $1970-78$ & 174145 & 132609 & 42926 & 76,1 \\
\hline $1979-88$ & 116601 & 32794 & 83807 & 28,1 \\
\hline $1989-91$ & 469044 & 345790 & 123254 & 73,7 \\
\hline Всего & 770005 & 521408 & 249987 & 67,7 \\
\hline
\end{tabular}

Ранние советские еврейские эмигранты в основном направлялись в Западную Европу и американские страны, причем США были основным пунктом переселения евреев-эмигрантов. Соответственно, большое количество евреев, прибывавших в США, неизбежно оказало значительное влияние на политику, экономическую, культуру и общество этой страны. В этот период 60\% всех советских евреев было моложе 35 лет, что, несомненно, обеспечило большими и дешевыми трудовыми ресурсами США. Оказали они влияние и на культурную составляющую. До Второй мировой войны, большое количество советских еврейских писателей вынуждено был эмигрировать в США, тем самым придав американской еврейской литературе достойное развитие (Мэри Антин, Авраам Каган, Анзя Езерска).

Однако еврейское эмиграционное движение повлекло внедрение традиций иудаизма в американское общество, привело к распространению негативного отношения к евреям и в конце концов превратилось в волну антисемитизма в США.

Огромное влияние еврейская эмиграция оказала и на палестино-израильский регион. В начале образования СССР многие евреи из Центральной и Восточной Европы переехали в Палестину, где они основали сотни поселений. Они обеспечили мощный рабочий потенциал в регионе и стали, по сути, «первопроходцами» и основателями Израиля, который оказался основным направлением эмиграции советских евреев. На данной территории произошло изменение структуры местного населения. В существующем этническом составе Израиля евреи являются крупнейшей национальностью, составив 70-78\% всего населения этой страны. Кроме того, советские евреи, переехавшие в Израиль после 1970-х годов, были высокообразованными, многие из которых 
работали врачами, учёными, инженерами и учителями в СССР. Эти евреи посодействовали развитию израильской науки, образования, культуры, здравоохранения, следовательно, обеспечили экономический рост Израиля в новом тысячелетии. Более того, многие советские евреи переехали в Израиль по призыву сионистского движения. Эмигранты старшего поколения начали активно участвовать в израильской политике и постоянно боролись за более высокий международный статус нового государства.

Среди проблем массовой эмиграции в Израиль оказалась национальная интеграция: разделение населения на восточных и западных эмигрантов. Из-за различия давних политических, экономических, культурных и др. убеждений и идеологии, интеграция между двумя различными еврейскими ветвями стала острой трудноразрешимой проблемой. Кроме того, интеграция еврейского народа с другими народами, особенно с арабами, привело к столкновениям на религиозной почве.

После распада СССР причина еврейской эмиграции была прежде всего связана с отношением к евреям в России, и это сосредоточенно выражалось в современном русском антисемитизме [2]. Хотя официальный антисемитизм ушёл со сцены истории России, но с ростом русского национализма антисемитские настроения в обществе вновь активизировались. Согласно исследованию российского социолога, Л.Д. Гудкова, около 6\%-9\% респондентов крайне предвзято относились к евреям, у 15\%-18\% респондентов было категорически негативное отношение к евреям, 35\%-52\% опрошенных выразили отрицательное отношение к евреям, и только около 18$20 \%$ опрошенных имели либеральное и толерантное отношение к данной национальности [2, с. 42].

В 1980-х и 1990-х годах в России начали процветать различные политические партии и общественные организации. Это также привело к тому, что многие правые экстремистские организации публично агитировали антисемитские настроения и пропагандировали антисемитские идеи в обществе под лозунгами «национал-патриотизм» и «русская расовая чистота», что также послужило образованию различных субкультур (в частности, «скинхеды»), которые осуществляли насильственные действия в отношении лиц различных национальностей, в том числе и евреев.

Согласно данным переписи населения 1989 года, в бывшем СССР насчитывалось 1,45 миллиона евреев, по сравнению с более чем 5 миллионами евреев в конце 19-го века [1]. Тогдашнее число советских евреев резко сократилось, и их доля среди всего населения России была очень малой. Основной причиной этой ситуации была еврейская эмиграция. С 1991 по 2000 год в странах бывшего Советского Союза наблюдался политиче- ский, экономический и социальный хаос, в сочетании с ростом социальных антисемитских настроений, что вызвало первую волну крупной еврейской эмиграции в постсоветскую эпоху. Тогда в общей сложности из стран бывшего СССР эмигрировало 1,14 миллиона евреев, а евреи-эмигранты из РФ составили около трети общего числа, достигая более 340000 человек. Более $60 \%$ из них эмигрировали в Израиль, а также в США и Германию.

С 2001 по 2010 год низкая рождаемость привела к снижению естественного прироста еврейского населения, что в свою очередь изменило тенденцию еврейской эмиграции. Кроме того, придя к власти, В.В. Путин принял ряд политических мер, чтобы улучшить российскую экономическую ситуацию, и увеличил поддержку еврейского образования и культуры. Данные факторы в определенной степени улучшили условия жизни евреев в России. В результате еврейская эмиграционная тенденция замедлилась и число русско-еврейских эмигрантов сократилось до 45000, из которых более половины переехали в Израиль, около 30\% - в Германию, небольшая часть - в США.

С 2011 по 2015 год в связи с падением международных цен на сырую нефть, крымским кризисом, санкциями США и другими международными ситуациями число еврейских эмигрантов из стран бывшего СССР в целом увеличивалось. Эта тенденция резко усилилась после 2014 года. В этот период около 51000 евреев из постсоветских государств эмигрировали за границу (более $90 \%$ евреев переехали в Израиль), а среди них около 20000 евреев приехали из России. Ниже приводится таблица (Табл. 2) с данными о численности еврейских эмигрантов и иммигрантов в РФ с 1990 по 2015 год.

Таблица 3.

Численность еврейских эмигрантов и иммигрантов в РФ с 1990 по 2015 год [5]

Численность еврейских эмигрантов и иммигрантов в РФ в 1990-2015 гг.

\begin{tabular}{|c|c|c|c|c|}
\hline \multirow{2}{*}{$\begin{array}{c}\text { Период } \\
\text { (годы) }\end{array}$} & \multicolumn{2}{|c|}{ Эмиграция из РФ } & \multicolumn{2}{|c|}{ Иммиграция в РФ } \\
\cline { 2 - 5 } & Всего & $\begin{array}{c}\text { В среднем } \\
\text { В год }\end{array}$ & Всего & $\begin{array}{c}\text { В среднем } \\
\text { В год }\end{array}$ \\
\hline 1990 -1997 & 38,4 & 4,8 & 3,7 & 0,4 \\
\hline 1998 -2004 & 90,5 & 12,9 & 10,8 & 1,5 \\
\hline 2005 -2009 & 16,8 & 3,4 & 5,1 & 1,0 \\
\hline $2010-2015$ & 25,8 & 4,3 & 3,9 & 0,6 \\
\hline Всего & 171,5 & 6,9 & 23,5 & 0,9 \\
\hline
\end{tabular}

В постсоветскую эпоху еврейская эмиграция - это потеря Российской Федерацией трудовых ресурсов, высококвалифицированных специалистов. Русские еврейские эмигранты также оказывают важное влияние на ситуацию на Ближнем Востоке и развитие российско-израильских отношений. Масштабное переселение евреев 
приводит к тому, что страны Ближнего Востока начинают более жесткую борьбу за землю, воду и другие ресурсы. И из-за этнических и религиозных противоречий еврейская эмиграция становится дестабилизирующим фактором в палестино-израильском и арабо-израильском конфликтах.

Одним из непосредственных результатов русско-еврейского иммиграционного движения в истории стало установление «русского мира» в Израиле. В настоящее время в Израиле ещё остаются те, кто по-прежнему знает русскую культурную традицию и используют русский язык в качестве своего родного языка. Таким образом русские еврейские эмигранты играют роль связующего звена в развитии отношений России и Израиля. В условиях неблагоприятной для России международной и внутренней ситуации. РФ и Израиль по-прежнему охраняют дружественные взаимоотношения, углубляют торгово-экономические обмены и поддерживают тесные координационное сотрудничество по сирийскому вопросу.

Таким образом, еврейская эмиграция в России обнаруживает длительную историю, охватывая почти 150 лет. Следует заметить, что данный процесс продолжается и в настоящее время в России и других странах бывшего СССР. Кроме того, возвращение еврейских иммигрантов в Россию также является важным явлением, которое нельзя обойти вниманием. Русская еврейская эмиграция является неотъемлемой частью всего мирового еврейского эмиграционного движения. На сегодняшний день, когда тенденция к глобализации становится все более очевидной, краткосрочная или долгосрочная миграция между различными странами и регионами является все более обычным явлением, отвечая различным повседневным потребностям, однако в ней представляется возможным обнаружить тесное взаимодействие между разными культурами, строящиеся на основе миграции.

Причины русско-еврейской эмиграции сложны, и в разные исторические периоды имеют свои особенности. Но нельзя отрицать того факта, что, когда речь идет о российском еврейском эмиграционном движении, оно обязательно связано с русским антисемитизмом. Русский антисемитизм сформировался в процессе развития русской истории (будь то официальный антисемитизм в царский период, политический и идеологический антисемитизм в советское время или общественный антисемитизм в постсоветский период). Он был результатом исторически религиозных и этнических противоречий. Поэтому, анализируя причины еврейской эмиграции в России, следует не только последовательно рассматривать эволюцию еврейского вопроса, но и уметь обобщать самые острые противоречия, проявившееся в различные периоды российской истории. Иными словами, исследование вопроса еврейской эмиграции должно как содержать материалистический взгляд на историю, так и использовать материалистическую диалектику.

Влияние русской еврейской эмиграции является многогранным и имеет исторический и глубокий характер. Россию она привела к хронической нехватке трудовых ресурсов и высококвалифицированных специалистов, интеллектуального потенциала, в конечном итоге к демографическому кризису. Возможно, действие этого кризиса будет постепенно распространяться на процесс политического, экономического, культурного, социального развития России, тем самым усиливая её дестабилизирующую ситуацию. Кроме того, русские еврейские эмигранты широко распространяются почти на всех континентах, живут в Израиле, США, Германии, Канаде, Аргентине и т.д., поэтому оказывают различное влияние и на эти страны и регионы. Еврейская эмиграция поспособствовала развитию еврейской культуры во всём мире, распространению иудаизма, в результате этого были основаны некоторые важные еврейско-культурные центры во многих странах. Еврейские эмигранты также оказали влияние на политические ситуации этих государств. Но наиболее интуитивным влиянием, которое евреи-эмигранты оказали на иммиграционные страны, является их экономический вклад. Отметим и тот факт, что вклад евреев в Израиль оказывается самым заметным: русские евреи помогли новому государству добиться плодотворных результатов в области научнотехнических исследований и значительно посодействовали развитию израильской экономики и культуры.

\section{ЛИТЕРАТУРА}

1. Альтшулер М. Евреи СНГ на пороге третьего тысячелетия [Электронный ресурс]. - URL: http://src-h.slav.hokudai.ac.jp/publictn/acta/16/alt/altshuler-4.html (дата обращения: 20.11.2020).

2. Гудков Л.Д. Параметры антисемитизма. Отношение к евреям в России, 1990-1997 // Мониторинг общественного мнения: экономические и социальные перемены. - 1998. - №2 (34). - С. 34-44.

3. Каганцов М. История евреев в России // 7x7 Горизонтальная Россия: электронный журнал [Электронный ресурс]. - 2013. - URL: https://7x7-journal.ru/ posts/2013/11/16/istoriya-evreev-v-rossii (дата обращения: 11.11.2020).

4. Клиер Д. Россия собирает своих евреев = Russia Gathers her Jews. - М.: Мосты культуры, 2000. - 352 c.

5. Миронов Б.Н. Кризис еврейской диаспоры в постсоветской России // Новейшая история России. - 2017. - №1. - С. 171-193. 
6. Пархомовский М., Харув Д. Сколько евреев эмигрировало из России и когда // Заметки по еврейской истории [Электронный ресурс]. - 2013. - №1. URL: berkovich-zametki.com/2013/Zametki/Nomer1/Parhomovsky1.php (дата обращения: 10.11.2020).

7. Прохожев А.А. Теневой народ (к истории евреев в России). - Барнаул: Полиграф-Сервис, 2002. - 72 с.

8. Россия. Демография еврейского населения Российской империи (1772-1917) // Электронная еврейская энциклопедия [Электронный ресурс]. URL: https://eleven.co.il/jews-of-russia/general/15443/ (дата обращения: 11.11.2020).

9. Советский Союз. Этническая демография советского еврейства // Электронная еврейская энциклопедия [Электронный pecypc]. - URL: https://eleven.co.il/ jews-of-russia/history-in-ussr/15423/ (дата обращения: 15.11.2020).

10. Стровский Д.Л., Антоншин А.В. Советская алия как важнейшая тема русскоязычной периодики Израиля: на примере журналов «Время и мы» и «22» // Вестник РУДН. Серия: История России. - 2018. - №2. - С. 320-356.

11. Тольц М. Постсоветские евреи в современном мире// ПоЛИТ.РУ: Электронная версия бюллетеня «Население и общество» [Электронный ресурс]. 2007. - URL: https://polit.ru/article/2007/10/14/demoscope303/ (дата обращения: 11.11.2020).

12. Черный С. Как жить российскому еврею: у иудеев появилось социальное учение// Независимая газета. - 2003. - №3. - С. 2.

13. 曹志宏.俄罗斯的反犹主义[J]. 俄罗斯中亚东欧研究, 2012(4).

14. 张娟. 沙俄时期反犹政策及其对犹太人命运的影响 (1881-1917)[D]. 陕西师范大学, 2010.

15. 宋全成. 欧洲犹太移民浪潮和以色列国家移民问题[J]. 文史哲, 2003 (2).

16. 徐继承. 以色列外来犹太移民与城市化发展[J]. 世界民族, 2011(2).

17. 周承. 以色列国内苏联犹太移民政党的成因及影响[J]. 西亚非洲, 2010 (8).

18. 白玉广. 试析苏联犹太移民问题的形成及影响[J]. 史学月刊, 2002 (4).

19. 梁中芳. 20世纪70年代苏联犹太移民问题历探源[J]. 河南师范大学学报, 2006 (5).

20. 余建华、康璇. 苏联对犹政策的历时考察[J]. 史林, 2007 (2).

21. 朱雯霞.沙俄政府的反犹政策与苏联政府对犹政策之比较[J]. 俄罗斯中亚东欧研究, 2004 (5).

22. 郭宇春. 简析俄国对犹太人政策的历史演变[J]. 西伯利亚研究, 2015 (6).

23. 王仙先. 20世纪末俄罗斯犹太移民问题研究[D].西北大学, 2008.

24. 朱威烈. 冷战结束前后以色列新一代俄裔犹太移民的形成及其影响研究[D]. 上海外国语大学, 2007.

25. 李秀姣. 俄罗斯与以色列关系“非常特殊”[J]. 世界态势, 2018 (22).

26. 张玉霞. 俄罗斯的犹太人一同化与移民[J]. 东欧中亚研究, 1999 (4).

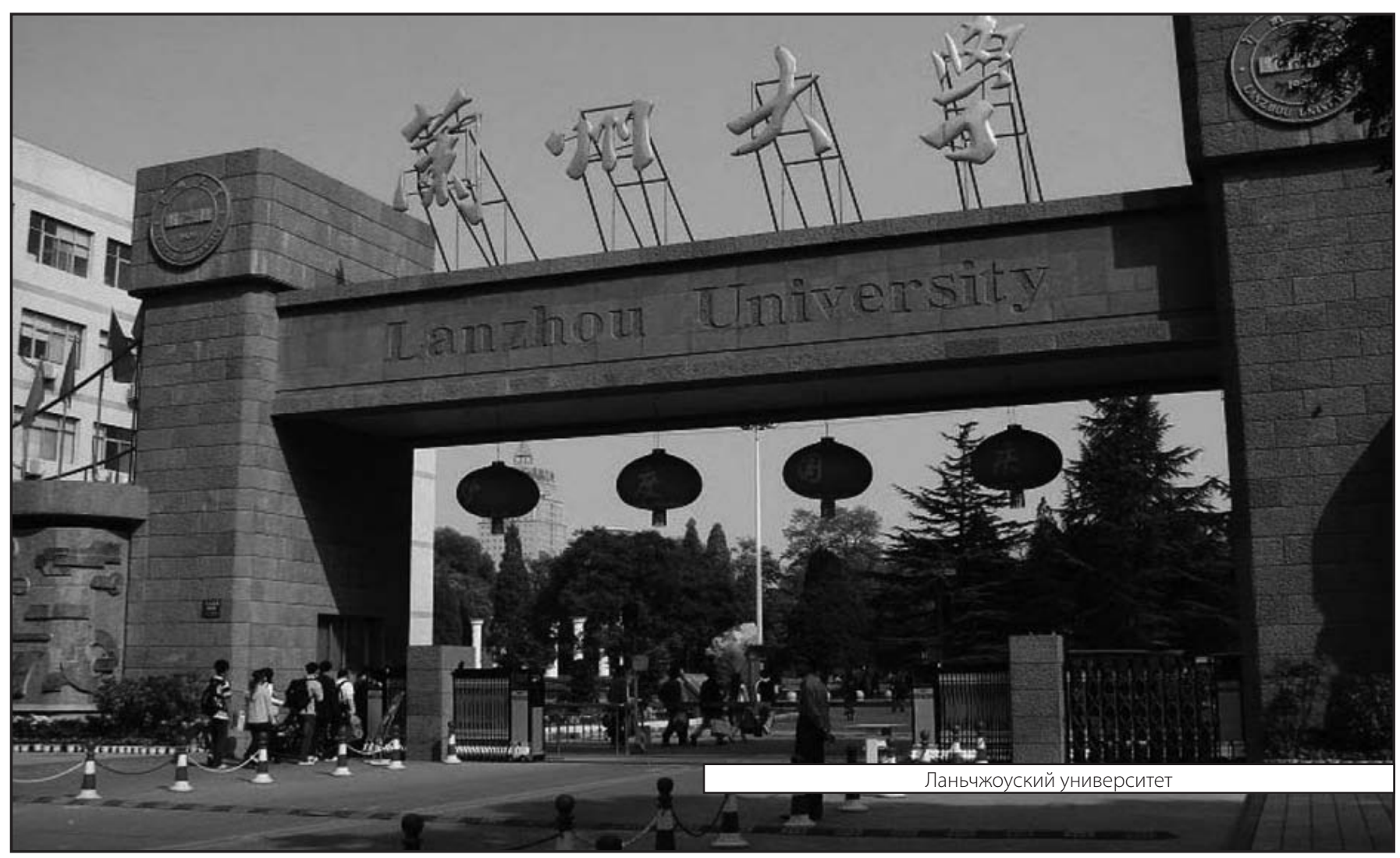

